\title{
Implementing Portfolio-Based Learning (PoBL) for L2 Training: Vietnamese EFL Learners' Motivational Orientations and Listening Achievement
}

\author{
Ngo Cong-Lem
}

Whilst previous researchers commonly report on the effect of portfolio-based instruction on second language/English as a foreign language (L2/EFL) learners' language performance, very few studies examine its impact on their learning motivation. Drawing on expectancy-value theory, the current study examines how the implementation of a portfolio-based listening course may affect language learners' L2 motivation and skill development. This study adopted a mixed methods approach with Vietnamese EFL learners in higher education as its participants, who were administered a motivation questionnaire, listening comprehension tests, and semi-structured interviews. Both quantitative statistics and qualitative content analysis were applied for data analysis purposes. The results indicated that the portfolio-based program in this study had a significant positive impact on the participants' motivational orientations, especially their expectancy components (i.e., their self-efficacy and learning control beliefs) and their L2 listening accomplishment but not on the value aspects. Pedagogical implications are discussed.

Alors que les chercheurs précédents font des rapports fréquents à propos des incidences sur la performance langagière des apprenants de langue secondel anglais langue étrangère (L2/ALE) qu'a l'instruction basée sur le portfolio, très peu d'études examinent son impact sur leur motivation d'apprentissage. En s'inspirant de la théorie de l'expectancy-value, la présente étude examine comment la mise en place d'un cours d'écoute basé sur le portfolio peut affecter la motivation et le développement des compétences des apprenants de langue seconde. Cette étude a adopté une démarche à plusieurs méthodes auprès d'apprenants universitaires d'anglais langue étrangère vietnamiens à qui on a administré un questionnaire de motivation, des tests de compréhension orale et des entrevues semi-structurées. On a appliqué à la fois des statistiques quantitatives et une analyse qualitative du contenu à des fins d'analyse des données. Les résultats ont indiqué que le programme de cette étude, basé sur le portfolio, avait un impact positif significatif sur les orientations motivationnelles des participants, particulièrement sur les composantes de leurs attentes (c'est-à-dire leur efficacité personnelle et leurs 
croyances dans le contrôle de l'apprentissage) et leurs résultats d'écoute, mais pas sur les aspects de valeur. On discute des implications pédagogiques.

Keywords: portfolio, learning motivation, Vietnamese EFL learners, L2 listening, alternative assessment

In recent decades, there has been a paradigm shift towards constructivism in the field of second language/English as a foreign language (L2/EFL) education. From the constructivist perspective, L2 learners' linguistic knowledge and skills are no longer perceived merely as being transmitted from their teachers, but instead, are actively constructed by the learners on the basis of their prior learning and experiences (Johnson, 1996; Lu \& $\mathrm{Wu}, 2018)$. This pedagogical shift has sparked interest among researchers to seek better methods for promoting learner autonomy and learner-centred classrooms (Jacobs \& Farrell, 2001).

In the field of L2/EFL education, portfolio-based learning (PoBL) emerges as a promising alternative to the conventional approach. It has been found to enhance students' learning autonomy, language outcomes, and digital skills (e.g., Chau \& Cheng, 2010; Hosseini \& Ghabanchi, 2014; Huang \& Hung, 2010; Hung, 2009; Tran \& Le, 2018). What is underexplored is whether and how PoBL may affect L2 learners' motivation (Douglas et al., 2019). Motivation, determining learning effort, engagement, and perseverance (Pintrich \& De Groot, 1990), is critical to outcomes of the language learning process (Ushioda, 2012).

Furthermore, previous research has largely capitalized on implementing PoBL for writing, speaking, and reading skills (Cong-Lem, 2019a), leaving whether and how PoBL can be applied to L2 listening training largely unknown (Ducker, 2013). L2 listening skill is critical for successful verbal communication as it enables L2 learners to understand their interlocutors' intentions and meanings. Yet, compared to other skills, it is "the least understood and least researched skill" (Vandergrift, 2007, p. 191).

The current study was carried out to address the above-mentioned gaps by investigating the effect of PoBL instruction on Vietnamese EFL learners' L2 motivation and listening skill. Findings in this study are expected to shed light on the pedagogical function of PoBL in L2 education, which can help L2 policymakers and educators to make more informed decisions on PoBL implementation. This study is part of a larger study that investigates the influence of self-regulated learning (SRL) capacity on Vietnamese language learners' L2 development. 


\section{Literature Review}

\section{Expectancy-Value Theory Perspective on Motivation}

Motivation is a complex and multidimensional construct, which has been variably defined. Lai (2011) defines motivation as the "reasons that underlie behaviour that is characterized by willingness and volition" (p. 2). To put it simply, motivation refers to the underlying motives of human behaviours, and is "critical to all forms of conscious and intentional human learning" (Ushioda, 2012, p. 58). It determines the amount of cognitive, metacognitive, and behavioural effort learners put into performing a task (He, 2005; Varasteh et al., 2016), which in turn results in their academic achievement (Pintrich \& De Groot, 1990).

The current study largely draws on expectancy-value theory (EVT; Eccles, 1983; Eccles \& Wigfield, 2002; Pintrich, 1989) to serve as its theoretical framework, helping to uncover the complexity and multidimensionality of motivation (Ushioda, 2012). Figure 1 visualizes key motivational orientations, of which expectancy and value are two overarching dimensions. The expectancy dimension "involves students' beliefs that they are able to perform the task and that they are responsible for their own performance" (Pintrich \& De Groot, 1990, p. 33). In the previous literature, self-efficacy and learning control beliefs constitute two major aspects of this expectancy dimension. The former is associated with learners' judgements of their capabilities to accomplishing the learning task (Bandura, 1977; Linnenbrink \& Pintrich, 2003), whereas the latter relates to "the belief that outcomes are contingent on one's own effort, in contrast to external factors such as the teacher" (Pintrich et al., 1991, p. 12). These expectancy aspects have been linked to "students' metacognition, their use of cognitive strategies, and their effort management" (Pintrich \& De Groot, 1990, p. 34). 
Figure 1

A Conceptual Model of Motivational Orientations in Expectancy-Value Theory, Adapted from Wigfield \& Eccles (2000)

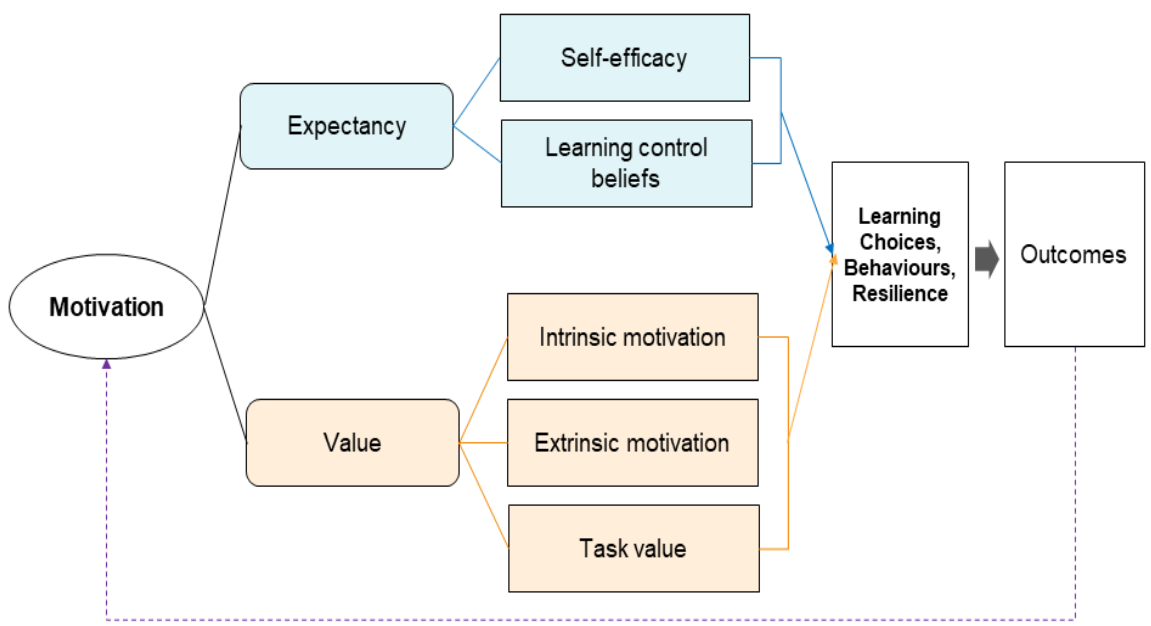

On the other hand, the value dimension involves intrinsic motivation, extrinsic motivation, and task value (Deci \& Ryan, 1985; Ryan \& Deci, 2000b). Intrinsic motivation concerns performing an activity out of enjoyment or pleasure, whereas extrinsic motivation regards externally oriented motives, for example, for grade or peer recognition (Ryan \& Deci, 2000a, 2000b; Wigfield \& Eccles, 2000). Task value refers to "student's evaluation of how interesting, how important, and how useful the talk is" (Pintrich et al., 1991, p. 15).

As depicted in Figure 1, expectancy and value dimensions are influential in students' willingness to learn, their behavioural effort and learning resilience, which in turn results in their outcomes. As to L2/EFL education, motivation is decisive to language learners' achievement (Ushioda, 2012) and a pedagogical approach to engage students motivationally is always desired by L2 educators. In the next section, I discuss PoBL as such an approach.

\section{Portfolio-Based Learning, L2 Motivation, and Listening Skill}

As educational reform has become a worldwide trend, the quest for more effective and innovative approaches in teaching has become an urgent task. Among new approaches to L2 teaching, the use of portfolio appears as a promising candidate for its process-oriented and learner-centred nature (Duong et al., 2011). Portfolio is defined as "a purposeful, interrelated collection of student work that shows the student's efforts, progress or achievement 
in one or more areas" (Paulson \& Paulson, 1991, p. 60). To put it simply, portfolio-based learning (PoBL) is a pedagogical approach where learners are allowed to create and collect their own learning artefacts as evidence for their learning progress. These artefacts are usually subject-specific and diverse in forms. For L2 learning purposes, they can involve written essays, reading logs, multimedia materials, reflections, self-assessment, and peer feedback (e.g., Baturay \& Daloğlu, 2010; Farahian \& Avarzamani, 2018; Hosseini \& Ghabanchi, 2014; Huang \& Hung, 2010; Kabilan \& Khan, 2012; Sharifi et al., 2017; Thang et al., 2012).

There is a growing body of literature examining the educational affordances of PoBL for L2 teaching and learning, including enhancing learners' motivation and language attainment (e.g., Aliweh, 2011; Aydin, 2010; Baturay \& Daloğlu, 2010; Charvade et al., 2012; Chau \& Cheng, 2010; Hung, 2012; Kabilan \& Khan, 2012). It has been established that the process-oriented nature of PoBL and its affordance for students' SRL are supportive for learners' motivation. For instance, Hashemian and Fadaei (2013) investigated whether PoBL benefitted Iranian EFL learners' SRL. In their study, the participants were allowed to write freely about their interest topics and then they submitted their writings for feedback. After 10 learning sessions, the participants were found to develop various SRL skills, including goal-setting, planning, and self-reflection skills. Whilst previous studies have richly documented the effect of PoBL on L2 achievement, very few have explored its impact of L2 motivation. For example, Sharifi et al. (2017) also found that PoBL approach could enhance both vocabulary knowledge and learning motivation for experimental-group participants.

Although previous researchers have mentioned motivation as an outcome for learners after participating in a PoBL program, very few have actually examined the construct of motivation comprehensively with a motivation theory. For instance, in the study by Sharifi et al. (2017), participants' L2 motivation was examined with a single item asking whether they felt more motivated in learning vocabulary. This is unlikely to allow the researchers to accurately assess participants' motivation which is a multidimensional construct as discussed in the previous section. Examining the effect of PoBL on L2 motivation is important in that it helps inform the design and implementation of PoBL pedagogy. If they are unmotivated, participants can be resistant to PoBL as a novelty approach, making it unlikely to be successful. As Burner (2014) puts it, "[i]t does not matter how productive PA [portfolio assessment] has proved to be if the students are not motivated" (p. 145).

Furthermore, although PoBL has been implemented to promote various L2 abilities, including writing skill (e.g., Aliweh, 2011; Farahian \& Avarzamani, 2018; Lam, 2013; Nicolaidou, 2013), speaking skill (e.g., Hung \& Huang, 2016), reading skill (e.g., Charvade et al., 2012; Hosseini \& Ghabanchi, 2014), and vocabulary learning (e.g., Sharifi et al., 2017), whether and how PoBL can be implemented for teaching L2 listening skill are relatively unknown. 
English listening is widely acknowledged as a challenging skill for language learners, yet it is critical for successful communication.

Listening is a highly complex process which is defined by Buck (2001) as the language learners' capacity to "process extended samples of realistic L2 speech, automatically and in real time, to understand linguistic information that is included within a text, and to make inferences based on information that are implicated by the content of the passage" (p. 114). This complex process is further influenced by various learner-related internal and external factors, which may involve their working memory, vocabulary, metacognitive knowledge, and pragmatic knowledge (Vandergrift, 2007). Motivational orientations such as self-efficacy have been found to influence the L2 listening performance. In this study, PoBL is implemented as a pedagogical approach, aiming to strengthen both L2 listening motivation and achievement of Vietnamese EFL learners.

\section{PoBL in Education Reform Contexts}

PoBL is especially embraced in educational reform contexts where L2 educators yearn for a more effective and innovative approach to L2/EFL education. This is true to both developed countries and many developing countries in Asia. Take Canada as an example of the former. Since 2013, with the initiation of Portfolio-based Language Assessment (PBLA), portfoliobased assessment has become a mandatory practice in Language Instruction for Newcomers to Canada (LINC; Abbott, 2019; Fox, 2014, 2015; Ripley, 2012), a federal program aiming to teach English to adult learners. Local researchers in Canada have indicated various advantages and limitations of the PBLA program. For instance, Ripley (2012) conducted semi-structured interviews with LINC instructors and found that the PBLA was reported to promote standardization among LINC programs, provide more detailed information of learners' strengths and weaknesses as well as encourage the use of rubrics in assessment. The concerned author also pointed out several limitations of PBLA implementation concerning conflict with existing curricular, teachers' increased workload, and the need for ongoing professional training.

As to developing countries such as Vietnam, PoBL has also been recognized as a useful alternative approach for L2 training. In Vietnam, with the initiation of the National Foreign Languages Project 2020 (NFLP 2020), EFL instructors are encouraged and, in some cases, required to implement new pedagogical approaches to enhance their students' language outcomes (e.g., Nguyen \& Bui, 2016; Phan, 2018). A few local researchers have examined the use of PoBL in the local context. For instance, Phung and Dang (2016) asked 34 undergraduate EFL learners to keep speaking portfolios over 15 weeks. They found that the PoBL approach facilitated the participants' learning autonomy and speaking competence. Likewise, Tran and Le (2018) examined how Facebook, a social networking site platform, could be utilized 
for hosting PoBL project. Their participants, 50 eleventh graders, were found to enjoy better peer interaction, receive more feedback, and possess enhanced self-efficacy. Yet, overall PoBL research in Vietnam appears to be scarce and periodic, which warrants further effort to explore how PoBL can be implemented in the local context.

\section{The Current Study}

The purpose of this study is threefold. First, it explores whether a PoBL listening course can facilitate the development of L2 learning motivation of Vietnamese EFL learners. Second, it examines whether the students could enhance their L2 listening ability after participating in the PoBL course. Finally, it probes into the participants' perception of the PoBL approach implemented for their listening course. Accordingly, three research questions in the current study are:

1. To what extent do the EFL learners' L2 motivational orientations change after participating in a PoBL listening course?

2. To what extent do the EFL learners' L2 listening achievement change after participating in a PoBL listening course?

3. What are the students' perceptions regarding the extent to which PoBL affects their motivation and L2 listening?

\section{Method}

\section{Participants and the Study Setting}

Participants of this study were 60 Vietnamese EFL learners, aged around 20 years old, who were in their second year of an English teacher education (ETE) program at Phu Dong University (pseudonym), located in the central region of Vietnam. The study participants have engaged in EFL education for approximately 7 years. Although no formal record of their English proficiency was reported, to the author's experience as a lecturer at the concerned institution, the participants should have possessed an intermediate level of English proficiency after 1 year in the program. The ETE program spans over 4 years and is designed to prepare them for English-related careers, especially English teachers.

The course participants took as part of this research is Listening 3, the third in a series of four mandatory English listening courses required in the ETE program. To be eligible for the course enrollment, participants must have passed their Listening 2, which assessed their L2 listening at the intermediate level. Listening 3 is designed to develop the participants' L2 listening skill 
at the upper intermediate level, that is, the fourth level (i.e., B2 level) of the Common European Framework of Reference for Languages (CEFR).

Participating in this study was voluntary with participants being fully informed of its purposes and that they would not be penalized if deciding not to take part in the project. Only participants who attended classes regularly and completed all of the study instruments were considered for the later data analysis. This reduced the number of participants to 38 .

\section{PoBL Listening Course Design and Development}

The PoBL implementation of this study was based on the common procedures utilized in previous studies (see Cong-Lem, 2019a). Major steps in PoBL implementation involve course planning, technical training, artefact creation, self/peer/teacher assessment, and artefact submission.

Stage 1: Planning and designing the PoBL listening course. The listening course spanned across 3 months, totalling 12 lessons. In designing the courses, students' SRL, personal interests, and sources of knowledge were of major considerations (see Cong-Lem, 2019a).

First, students' SRL was supported with reflective activities, including self-assessment, peer assessment, and individual conferences with the instructor. These activities were designed with guiding questions to assist learners in setting goals, monitoring learning effectiveness, and reflecting on strengths and weaknesses. Participants were asked to engage in blogging activities where they could share personal reflections, listening materials, and their outside-of-classroom learning activities. Finally, to enable students to learn from multiple sources of knowledge (i.e., from peers, teachers, and materials), a large portion of the learning tasks were designed in the form of pair and group work with the instructor being a responsive facilitator.

Stage 2: Technical preparation and training. The first lesson was reserved for technical training and informing participants of general information about the course. The EFL learners were instructed on how to utilize web-based and mobile technologies (including blogging platforms, QR code, Google Forms) and online resources (e.g., Google and YouTube) to search and retrieve relevant listening materials. A website and a Facebook group were created by the instructor to provide the participants with a space to interact and share learning resources.

Stage 3: Artefact creation. Participants were allowed to create various forms of learning artefacts, which involved blog posts (i.e., about listening-related topics), multimedia materials (i.e., listening audio, videos), listening logs, and others. These artefacts could be created at home or during the lesson as the instructor also encouraged them to share what they learned in class in their blogs. Another type of artefact for the participants was teacher-generated learning performance charts, which is elaborated in the next stage. In short, 
participants had their artefacts hosted both online (e.g., performance charts, personal blog websites) and offline (e.g., listening books, assignments).

Stage 4: Assessment and reflection. Assessment of participants' performance was conducted in three forms, namely self-assessment, peer-assessment, and listening tests at the end of each lesson, which were created online using Google Forms. First, self-assessment forms asked students to reflect on their strengths and weaknesses in L2 listening skill, their future goals, and action plan to address these limitations. As to peer assessment, the participants were graded by at least two peers who worked in the same group with them during the lesson. Four criteria for peer assessment include class regulation (i.e., discipline), sharing for community (i.e., blog posts), contribution to group work, and contribution to the whole-class discussion. At the end of the lesson, the EFL learners took a short listening test. The peer assessment and listening test scores were utilized to create an individual-based performance chart for each participant which they could access online at any time (see Figure 2). This chart was updated weekly, aiming to help individual students to monitor their learning progress.

Individual conferences with the instructor were organized twice, once at the third lesson and once at the seventh lesson. In these sessions, the participants discussed with the instructor their learning progress, future goals, and action plan.

Figure 2

An Example of the EFL Learners' Learning Performance Chart

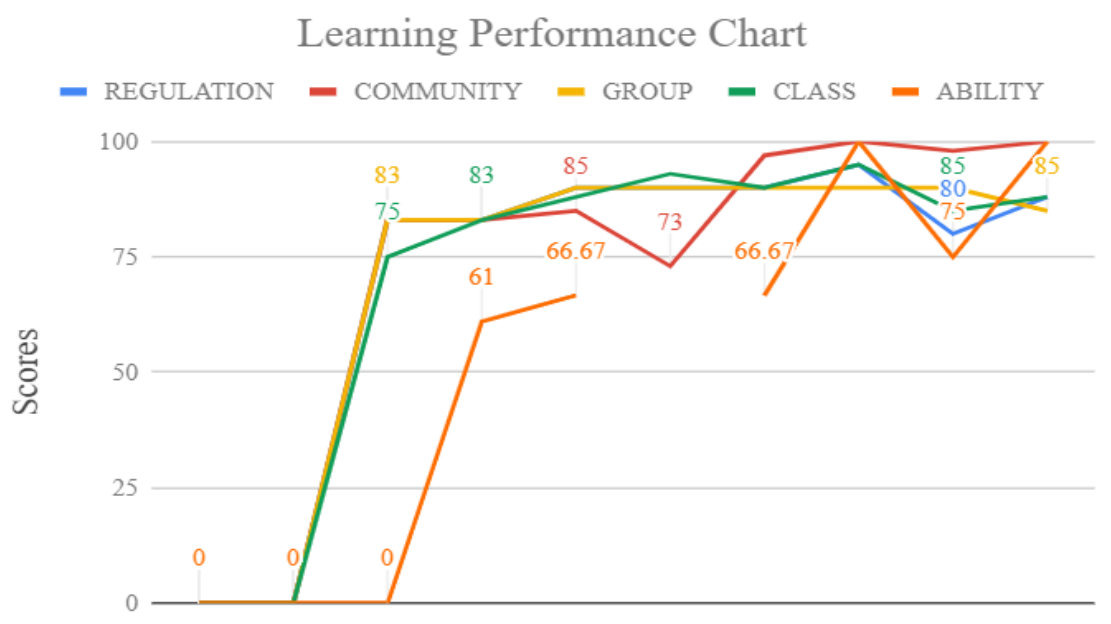

Lessons (1-12) 
Notes: REGULATION = peer assessment $(P A)$ score on the individual's classroom regulation; COMMUNITY = PA score for participants' blogging; GROUP $=P A$ score for contribution to group work; CLASS $=P A$ score for contribution to class discussion; ABILITY = score from their listening test in each lesson.

Stage 5. Submission of artefacts. Students were asked to submit all of their artefacts to the teacher at the end of the course.

\section{Instruments}

The current research adopted a mixed methods design with quantitative measures involving L2 listening motivation questionnaire and two listening tests. Semi-structured interview was utilized as the instrument to collect further qualitative data for the study.

\section{L2 Listening Motivation Scale}

In order to examine learners' motivational orientations towards acquiring L2 listening skill, the author utilized an L2 Listening Motivation Scale (L2LMS) instrument, consisting of 31 items, adopted from the Motivated Strategies for Learning Questionnaire (MSLQ) by Pintrich et al. (1991). The MSLQ was chosen for its validity and reliability which has long been attested in numerous studies (see Pintrich et al., 1993).

The L2LMS features two main components, namely value and expectancy. The value component is subdivided into three subscales: intrinsic motivation (4 items), extrinsic motivation (4 items), and task value (6 items), whereas the expectancy component is divided into two subscales: learning control beliefs (4 items) and self-efficacy (8 items). Examples of these items are provided in Table 1. The items are formulated as 7-point Likert scale statements, ranging from "not at all true of me" to "very true of me." Cronbach's $\alpha$ value for the overall instrument is .92, with its subscales varying from .72-.87, suggesting an adequate level of its internal consistency (see Table 2).

\section{Listening Comprehension Tests}

To assess the L2 listening ability of the EFL learners, they were administered two listening comprehension measures for pretest and posttest purposes. Items of these two tests were adopted from a commercial book for training English listening, that is, Skills for First Certificate-Listening and Speaking, published by MacMillan Publisher. The pretest consists of two sections, the first involving eight three-option multiple-choice questions for eight short conversations and the second featuring 10 questions asking the students to fill in the blanks with one or two words after listening to an interview. The listening posttest involves two sections, the first of which was a matching question, requiring participants to pick out five answers from a list of six to describe the intention of five speakers. The second section asked the students 
to listen to an interview and answer another seven three-option multiplechoice questions. The maximum scores for these tests are 18 points. According to the test manual from the publisher, both tests were designed to assess B2 level (i.e., the fourth level of CEFR), and thus assumed equivalent in assessing the participants' L2 listening skill. The training and implementation of these CEFR-format listening tests are in accordance with policies at the institution.

\section{Interview}

Further qualitative data was collected by conducting semi-structured interviews with four participants who volunteered. These interviews were conducted online with individual participants, each lasting 30 minutes and being audio-recorded with their permission. Guiding questions for the interviews were: "What do you think about the learning tasks employed in Listening 3 course, including blogging, self-assessment, peer assessment, performance chart, and individual conferences with the instructor?", "In what ways do you think these activities affect your motivation to learn English listening?", "In what ways do they influence your development of English listening ability?", and "What would be your advice for future improvements of these tasks?" These questions were dynamically rephrased during the interviews to suit the students' level of understanding. Both English and Vietnamese were allowed in the interviews with all participants opting for the latter, that is, their mother tongue. Participants' names used in this study are pseudonyms for protection of their identity. 
Table 1

Sample of L2LMS Items

\begin{tabular}{|c|c|c|}
\hline Components & Scales & Sample of items \\
\hline \multirow{6}{*}{ Value } & \multirow{2}{*}{ Intrinsic } & $\begin{array}{l}\text { 1. In a class like this, I prefer course material that really } \\
\text { challenges me so I can learn new things. }\end{array}$ \\
\hline & & $\begin{array}{l}\text { 2. In a class like this, I prefer course material that } \\
\text { arouses my curiosity, even if it is difficult to learn. }\end{array}$ \\
\hline & \multirow[b]{2}{*}{ Extrinsic } & $\begin{array}{l}\text { 1. Getting a good grade in this class is the most } \\
\text { satisfying thing for me right now. }\end{array}$ \\
\hline & & $\begin{array}{l}\text { 2. I want to do well in this class because it is important to } \\
\text { show my ability to my family, friends, employer, or others. }\end{array}$ \\
\hline & \multirow[b]{2}{*}{ Task value } & $\begin{array}{l}\text { 1. I think I will be able to use what I learn in this course in } \\
\text { other courses. }\end{array}$ \\
\hline & & 2. I am very interested in the content area of this course. \\
\hline \multirow{4}{*}{ Expectancy } & \multirow{2}{*}{$\begin{array}{l}\text { Learning } \\
\text { control beliefs }\end{array}$} & $\begin{array}{l}\text { 1. It is my own fault if I don't learn the material in this } \\
\text { course. }\end{array}$ \\
\hline & & $\begin{array}{l}\text { 2. If I try hard enough, then I will understand the course } \\
\text { material. }\end{array}$ \\
\hline & \multirow[b]{2}{*}{ Self-efficacy } & $\begin{array}{l}\text { 1. I'm confident I can do an excellent job on the } \\
\text { assignments and tests in this course. }\end{array}$ \\
\hline & & $\begin{array}{l}\text { 2. I'm certain I can understand the most difficult material } \\
\text { presented in the readings for this course. }\end{array}$ \\
\hline
\end{tabular}

\section{Procedure}

For data collection, the participants were administered the data collection instruments in the third and the last lessons. The questionnaire was administered to them at the beginning of their lesson, whereas the listening test towards the end. In the third lesson, after warm-up activities and participants having completed one listening exercise in the textbook, they were asked to access the L2LMS hosted online with Google Forms, which they had 20 minutes to complete. After the questionnaire, they finished another listening exercise before having a break, and then engaged in other typical activities for the class (i.e., group work, mini listening test, and peer assessment). In the last lesson of the course, towards the end of the lesson, the participants were administered the 30-minute listening tests towards the end of the class. 
During the survey administration, students were advised not to discuss or share their answers with others. Likewise, as the listening tests were part of their formal course assessment, the students were warned against cheating and the teacher researcher did his best in ensuring no students received help during the test administration.

To recruit participants for the individual interviews, invitation emails were sent out to all course participants with relevant information about the interview provided. Participants who agreed to be interviewed were then contacted to arrange online meetings.

\section{Data Analysis}

SPSS software version 26 was utilized for data analysis in this study. In this study, the time (for pre- and posttest administration) acts as the independent variable, whereas motivational dimensions and listening scores serve as the dependent variables. First, descriptive statistics were performed for all of the study variables. Subsequently, repeated multivariate analysis of variance (MANOVA) was carried out to address the first research question, concerning the difference in L2 listening motivation of the participants. Finally, a paired t-test was performed to explore whether the participants have significantly improved their L2 listening ability after attending the PoBL course.

As to the qualitative data, the interview audios were transcribed and then subject to content analysis (Elo \& Kyngäs, 2008; Hsieh \& Shannon, 2005). The qualitative analysis featured an inductive and iterative process with emerging themes grouped together. The researcher first read through the interview transcripts to get a sense of their overall meaning. Then, they were read carefully with meaningful segments of data identified and coded into preliminary nodes. Next, these nodes were subsumed into larger and more abstract categories based on their similarity and conceptual connection. Finally, these abstract categories were grouped into major themes selected for reporting.

\section{Findings}

\section{Quantitative Findings}

\section{Descriptive Statistics}

First, information about the internal consistency reliability of the L2LMS and its subscales are described in Table 2. Next, Table 3 presents the descriptive statistics of the study variables. The total score for each motivation orientation is the average score for its sub-items (i.e., on a 7 Likert-scale point). 
Table 2

Internal Consistency Values for L2LMS Overall and its Subscales

\begin{tabular}{lll}
\hline \multirow{2}{*}{ L2LMS Subscales } & \multicolumn{2}{c}{ Internal Consistency (Cronbach's a) } \\
\cline { 2 - 3 } & Pre-L2LMS & Post-L2LMS \\
& $(\boldsymbol{N}=\mathbf{5 8})$ & .74 \\
\hline Intrinsic & .78 & .72 \\
Extrinsic & .79 & .86 \\
Task value & .87 & .68 \\
Learning control beliefs & .75 & .82 \\
Self-efficacy & .87 & .92 \\
Overall & .92 & \\
\hline
\end{tabular}

Note: L2LMS = L2 Listening Motivation Scale

According to Table 3, there is an increase in all of the EFL learners' L2 learning motivational orientations except for their extrinsic motivation. To elaborate, the study participants demonstrated a higher sense of intrinsic motivation, task value, learning control beliefs, and self-efficacy. Their L2 listening ability also witnesses an increase. Overall, these descriptive statistics suggest a positive development in the participants' L2 motivation and listening ability. In the next sections, the research questions of this study are addressed.

\section{Table 3}

A Summary of Descriptive Statistics for the Study Variables

\begin{tabular}{lllll}
\hline \multirow{2}{*}{ Variables } & \multicolumn{2}{c}{ Pre } & \multicolumn{2}{c}{ Post } \\
\cline { 2 - 5 } Intrinsic & Mean & SD & 5.11 & SD \\
\cline { 2 - 5 } Extrinsic & 4.89 & 1.06 & 5.16 & .69 \\
Task value & 5.28 & 1.24 & 5.24 & .92 \\
Control beliefs & 5.07 & 1.00 & 5.44 & .87 \\
Self-efficacy & 5.08 & 1.03 & 4.84 & .86 \\
Listening ability & 7.37 & .90 & 11.33 & .71 \\
\hline
\end{tabular}


Research Question 1: To what extent do the EFL learners' L2 motivational orientations change after participating in a PoBL listening course?

In order to address the first research question, which concerns the development of motivational orientations of the participants, a repeated MANOVA was performed. The result indicates a statistically significant difference in L2 listening motivation before and after participating in the PoBL course: Wilks' $\Lambda=.64, F(6,32)=3.05, p<.05, \eta 2=.036$.

Table 4 displays the results of MANOVA univariate tests for different motivational components. The PoBL course was found to significantly enhance the students' learning control beliefs and self-efficacy, $F(1,37)=4.40$, $p<.05, \eta 2=.11$ and $F(1,37)=12.85, p<.01, \eta 2=.26$. The improvement in other motivational aspects, nevertheless, fails to reach statistical significance.

Table 4

Results of Univariate Tests Regarding the Effect of PoBL Listening Course on Motivational Dimensions of the Participants

\begin{tabular}{llll}
\hline Variables & $F$ & $p$ & $\begin{array}{l}\text { partial eta } \\
\text { squared }(\eta 2)\end{array}$ \\
\hline Intrinsic & 1.89 & .18 & .05 \\
Extrinsic & .35 & .56 & .01 \\
Task value & 1.25 & .27 & .03 \\
Control beliefs & 4.40 & .04 & .11 \\
Self-efficacy & 12.85 & .00 & .26 \\
\hline
\end{tabular}

On the whole, the implementation of the PoBL approach was found to have a positive impact on the learners' motivation, especially for the expectancy dimension.

Research Question 2: To what extent do the EFL learners' L2 listening achievement change after participating in a PoBL listening course?

A paired t-test was carried out to address the second research question regarding whether participants improved their L2 listening ability after taking part in the PoBL course. The result indicates a statistically significant increase in learners' L2 listening ability, $t(1,29)=4.29, p=.0001$. Accordingly, the participants were found to have significant improvement in their listening ability after attending the PoBL course. In the next section, further qualitative findings are provided to help explain more clearly how PoBL influenced the course participants' motivation and L2 listening.

\section{Qualitative Findings}

Research Question 3: What are the students' perceptions regarding the extent to which PoBL affected their motivation and L2 listening? 
Individual interviews with four participants (i.e., Hoa, Dat, Thang, and Duyen) revealed that they overall felt positive about the effect of PoBL on their motivation and L2 listening skill, especially in three aspects: (1) making the listening practices more interesting and meaningful learning experiences; (2) enhancing their SRL; and (3) L2 listening ability. First, participants reported that compared to conventional L2 listening classes, PoBL was more interesting and provided more individual-based learning experiences:

Listening 3 was interesting to me as I learned a lot of new things during the course. For example, the performance chart helped me to monitor my learning progress every week for more self-study, which makes the course more interesting compared to other classes. (Hoa)

The teaching method in Listening 3 is totally different from the teaching approaches from other classes that I have experienced. Before Listening 3 , we were mainly taught with more traditional methods, starting with exercises, then group work and then taking test. In Listening 3, we had blogging activity and weekly updated performance chart, which are all very new and useful to me. (Duyen)

Second, participants further attributed their enhanced SRL to the PoBL tasks, including self-assessment, peer assessment, learning chart performance, and conferences with the instructor:

After taking the course [Listening 3], through self-reflection activities such as self-assessment and performance chart, I realized other weaknesses in English listening that I still needed to improve such as vocabulary, the ability to stay focused, and listening for details. I subsequently created my own plan to improve them. (Dat)

Thanks to self-assessment activities, I knew how to plan my study better and manage my time more effectively to complete listening tasks. Whenever I finished a listening task, I would reflect on my mistakes. I mean, why I got that answer wrong. Then, I noted down my mistakes and made a plan to fix them. (Hoa)

Finally, when asked about how PoBL could have impacted their L2 listening skill, all participants attributed their skill enhancement partly to the mediating role of PoBL approach:

I think the teaching method applied in Listening 3 is important and influential in my English listening achievement. After attending the course, my listening ability has significantly increased compared to previous listening courses I took, especially in doing multiple-choice and fill-in-the-blank questions, significantly improved. Before Listening 3, my IELTS score was 6.5, then after Listening 3, it jumped to 7.5. I mean, after 
I practiced with appropriate methods, my listening ability has improved. (Hoa)

In my opinion, the teaching method is quite influential in my listening ability. In previous courses, I did have learning experiences with some similar tasks, yet it was merely for the sake of completing the procedure. In Listening 3, I really needed to put effort into accomplishing the tasks. (Thang)

The participants also discussed limitations related to the PoBL approach. First, prior ability and experiences stood out as significant factors influencing their PoBL experiences:

Many of us have already gotten used to the conventional learning styles in previous listening courses like analysing the listening exercise, completing them and correcting them with teachers, and then go home. That's it. So, it was challenging for some to adjust to a new method. (Hoa)

I knew some classmates who could not do the blogging task very well since they were not used to doing it and some even did not have computers to do it. For me, however, blogging was pretty simple as I often work with computers in my part-time job. (Dat)

Furthermore, time constraint and course-specific content are additional moderating variables affecting the participants' accomplishment of the PoBL tasks:

I think blogging is an interesting task. However, at the time when I studied Listening 3, my time was rather tight due to taking many courses, so I did not have much time for writing my blogs. (Hoa)

The content of Listening 3 was quite challenging, and the implementation of a new pedagogical approach added significantly to the course demand. (Hoa)

The participants also raised concerns about the validity and reliability of peer assessment:

For peer assessment, my friends tend to copy each other in giving scores to their classmate, so I think it would be fairer if students are separated when peer assessing each other. (Hoa)

Peer assessment may not be that reliable because I don't think students provide an accurate or honest assessment of their friends. (Thang) 


\section{Discussion}

\section{PoBL for Promoting L2 Listening Motivation and Listening Skill}

The current study set out to explore whether the participants' L2 motivation and listening ability improved after joining the PoBL course. The results found in this study indicate a positive answer to both aspects. Although the pre- and posttest study design without a control group would not allow for the conclusion that PoBL was the main factor for participants' improvements, qualitative findings do lend support that PoBL tasks played a crucial role in such process.

On the one hand, PoBL was found to exert its significant positive effect on the expectancy dimension of the EFL learners' motivation (i.e., self-efficacy and learning control beliefs). The PoBL participants were found to possess a higher level of controllability over their learning (i.e., their SRL capacity) as well as expectancy-for-success beliefs in L2 listening. This was attributed by the participants largely to the reflection tasks they took (i.e., self-, peer assessment, individual conferences with the instructor), which enhanced their awareness of personal strengths and weaknesses. Expectancy beliefs have been consistently found to be associated with L2 attainment (e.g., CongLem, 2019b; Ngoc Truong \& Wang, 2019).

Compared to the expectancy dimension, the value dimension of participants' motivation (i.e., intrinsic motivation, extrinsic motivation, and task value) appeared to be more stable and harder to change. No significant effect of PoBL tasks was confirmed for these motivational orientations. This result lends support to the claim that L2 motivation is relatively stable and hard to change (Nitta, 2013) and that intrinsic motivation is the least likely to change (Gardner et al., 2004). Several factors could contribute to this finding. First, the length of the course in this study lasted only for 2.5 months, just above one-fifth of Gardner et al. (2004)'s study. A longer duration of implementation would allow participants to better familiarize themselves with the new technologies and PoBL approach, reflected in the qualitative findings discussed above. Second, as observed by the teacher-researcher, most participants started their Listening 3 with inadequate L2 listening skill as some of them acknowledged during the individual conferences with their teacher. This tends to be exacerbated with the significantly more challenging course materials in Listening 3 compared to Listening 2, the preceding course. Finally, the time constraint (i.e., due to heavy course content) and the examination-oriented culture at the concerned institution (e.g., English proficiency as a graduation benchmark) put many students under pressure to study for grades and certificates so as to graduate in time. All of these contextual factors could have adversely affected the students' development of motivation for genuine learning purposes. 
Qualitative findings from interviews with participants affirmed several factors negatively affecting their PoBL learning experiences, involving learners' prior L2 ability and learning experiences, course content, time constraint, and perception of peer-assessment reliability. These findings lend support to previous literature regarding the learner-related and contextual factors (e.g., Aydin, 2010; Hung, 2012; Kabilan \& Khan, 2012; Thang et al., 2012), which should be addressed for successful PoBL programs. In summary, this study has provided empirical evidence to support the advantageous mediating role of PoBL approach for L2 learners' motivation and language development (e.g., Farahian \& Avarzamani, 2018; Phung \& Dang, 2016; Sharifi et al., 2017). Yet, this study is among the very few that implemented PoBL for L2 listening training.

\section{Pedagogical Implications}

Several pedagogical implications are recommended for more effective PoBL implementation in the future. First, a well-planned syllabus/curriculum appears to be a must, which should involve learner-appropriate course materials, number of assignments, and sufficient time for students to familiarize themselves with and function effectively in a new learning environment. Second, PoBL designers should base their programs on wellestablished motivation theories, for instance, the expectancy-value theory in this case for motivation is conceivably the most challenging issue in carrying out PoBL programs (Burner, 2014). Accordingly, PoBL tasks should be designed in ways that support language learners' genuine learning interest, perception of task value, expectancy for success, and SRL capacity. Several useful approaches adopted in the previous literature involving personalizing learning tasks (i.e., relating lesson content to learners' real-life experiences), using authentic materials, portfolio sharing (e.g., Clark et al., 2001; CongLem, 2018; Hung, 2012; Peacock, 1997), and using performance chart in this study.

Second, the present research also has implications for the role of educational technologies in PoBL implementation. In this study, both mobile and web-based technologies played a critical role in making the L2 listening course ubiquitous to participants. Whilst web-based technologies (e.g., Google Forms) were used to create online forms (i.e., for information collection and assessment purposes), mobile phones allowed the participants to complete these forms in a convenient way. In short, the adopted technologies are open source and widely available, yet they are powerful tools if teachers are trained to take advantage of them for their teaching.

Third, it is essential for L2 educators to account for possible learnerrelated factors and contextual constraints in designing and implementing PoBL programs. For technology-involved PoBL projects, both instructors and learners should receive adequate technical training and ongoing support. 
Moreover, as carrying out PoBL tasks is usually effortful and time-consuming (e.g., Aydin, 2010), L2 instructors should aim for an optimal amount of workload and try not to overload the learners, which causes anxiety and negative attitude towards PoBL approach. This is especially important in situations where PoBL approach is integrated into existing curriculum such as the case of this study or of LINC programs in the Canadian context (Ripley, 2012).

PoBL was not used for its assessment purpose in this study, yet it did generate a positive effect on the participants' L2 motivation and achievement. This suggests that PoBL is functioning as a pedagogical approach in addition to its conventional role as an alternative assessment tool. L2 educators should thus focus on the pedagogical value of PoBL as well. Only when PoBL is well designed and effectively performed that the learners are likely to benefit from the approach. This is meaningful to contexts where portfolio assessment is mandated for assessment purpose such as the case of LINC programs in Canada.

\section{Conclusion}

The current study was conducted to address previous research gaps by investigating the effect of portfolio-based training on EFL learners' motivation and L2 listening skill. The findings support a positive impact of the portfoliobased course on the expectancy dimension of the participants' motivational orientations and their listening ability. Pedagogical implications for educators involve the use of motivation theory to inform the design of PoBL tasks, utilizing mobile and web-based technologies, accounting for learner-related and contextual constraints, and making use of the pedagogical function of PoBL.

This research is, however, not without limitations. First, the current study has been conducted with a limited number of participants. Yet, for studies adopting repeated measures with the same population, there is usually a trade-off between practicality and validity (Nitta, 2013). Second, the lack of a control group in this study design also prevents it from ruling out potential confounding factors which may contribute to the enhancement or hindrance of participants' motivation and L2 listening development, for example, the washback effect from testing and curriculum of the listening course. The differential format of the two listening tests might have also affected students' L2 listening performance. Future research should adopt a true experimental design with a larger number of participants and with standardized tests to provide stronger empirical evidence for the affordance of PoBL approach in L2 education. Despite the above limitations, the current study has pioneered in examining the impact of PoBL on language learners' motivation and L2 listening skill with the adoption of expectancy-value theory, paving the way for further research on this under-explored topic. 


\section{Acknowledgement}

I acknowledge the support of Australian Government Research Training Program (RTP) Scholarship and Monash International Tuition Scholarship (MITS) during the writing of the article. My special thanks also to all of the participants who made this study possible and to the two anonymous reviewers for their valuable comments and efforts towards improving this manuscript.

\section{The Author}

Ngo Cong-Lem is a former lecturer at Dalat University, and is currently a $\mathrm{PhD}$ candidate at Monash University, Australia. He was awarded a master's degree from the National Taiwan University of Science and Technology, Taiwan. His research interests involve TESOL, computerassisted language learning, and teacher professional development.

\section{References}

Abbott, M. L. (2019). Developing an interpretive argument to guide the use of portfolio-based language assessment in beginning adult English language literacy classes. Pathways to Prosperity. http:// p2pcanada.ca/wp-content/blogs.dir/1/files/2019/07/Portfolio-based-Language-Assessmentin-Beginning-Adult-English-Language-Literacy-Classes.pdf

Aliweh, A. M. (2011). The effect of electronic portfolios on promoting Egyptian EFL college students' writing competence and autonomy. Asian EFL Journal, 13(2), 90-132.

Aydin, S. (2010). EFL writers' perceptions of portfolio keeping. Assessing Writing, 15(3), 194-203. https://doi.org/10.1016/j.asw.2010.08.001

Bandura, A. (1977). Self-efficacy: Toward a unifying theory of behavioral change. Psychological Review, 84(2), 191-215. https://doi.org/10.1037/0033-295x.84.2.191

Baturay, M. H., \& Daloğlu, A. (2010). E-portfolio assessment in an online English language course. Computer Assisted Language Learning, 23(5), 413-428. https://doi.org/10.1080/095882 21.2010.520671

Buck, G. (2001). Assessing listening. Cambridge University Press.

Burner, T. (2014). The potential formative benefits of portfolio assessment in second and foreign language writing contexts: A review of the literature. Studies in Educational Evaluation, 43, 139-149. https://doi.org/10.1016/j.stueduc.2014.03.002

Charvade, M. R., Jahandar, S., \& Khodabandehlou, M. (2012). The impact of portfolio assessment on EFL learners' reading comprehension ability. English Language Teaching, 5(7), 129-139. https://doi.org/10.5539/elt.v5n7p129

Chau, J., \& Cheng, G. (2010). Towards understanding the potential of e-portfolios for independent learning: A qualitative study. Australasian Journal of Educational Technology, 26(7). https://doi. org/10.14742/ajet.1026

Clark, C., Chow-Hoy, T. K., Herter, R. J., \& Moss, P. A. (2001). Portfolios as sites of learning: Reconceptualizing the connections to motivation and engagement. Journal of Literacy Research, 33(2), 211-241. https://doi.org/10.1080/10862960109548110

Cong-Lem, N. (2018). A review of research in mobile-assisted collaborative language learning. VNU Journal of Foreign Studies, 34(4), 71-82. https://doi.org/10.25073/2525-2445/vnufs.4282

Cong-Lem, N. (2019a). Portfolios as learning and alternative-assessment tools in EFL context: A review. CALL-EJ, 20(2), 165-180.

Cong-Lem, N. (2019b). Self-regulated learning and its relation to Vietnamese EFL learners' L2 listening achievement. VNU Journal of Foreign Studies, 35(4), 60-74. https://doi. org/10.25073/2525-2445/vnufs.4395

Deci, E. L., \& Ryan, R. M. (1985). Intrinsic motivation and self-determination in human behaviour. Plenum. https://doi.org/10.1007/978-1-4899-2271-7

Douglas, M. E., Peecksen, S., Rogers, J., \& Simmons, M. (2019). College students' motivation and confidence for e-portfolio use. International Journal of ePortfolio, 9(1), 1-16. 
Ducker, N. (2013). Self-directed Internet-based extensive listening portfolios. 38th Annual International Conference on Language Teaching and Learning \& Educational Materials Exhibition, Tokyo.

Duong, M. T., Cuc, N. T. K., \& Griffin, P. (2011). Developing a framework to measure processoriented writing competence: A case of Vietnamese EFL students' formal portfolio assessment. RELC Journal, 42(2), 167-185. https://doi.org/10.1177/0033688211402179

Eccles, J. S. (1983). Achievement and achievement motives. Freeman.

Eccles, J. S., \& Wigfield, A. (2002). Motivational beliefs, values, and goals. Annual Review of Psychology, 53(1), 109-132. https://doi.org/10.1146/annurev.psych.53.100901.135153

Elo, S., \& Kyngäs, H. (2008). The qualitative content analysis process. Journal of Advanced Nursing, 62(1), 107-115. https://doi.org/10.1111/j.1365-2648.2007.04569.x

Farahian, M., \& Avarzamani, F. (2018). The impact of portfolio on EFL learners' metacognition and writing performance. Cogent Education, 5(1), 1450918. https://doi.org/10.1080/23311 86x.2018.1450918

Fox, J. (2014). Portfolio based language assessment (PBLA) in Canadian immigrant language training: Have we got it wrong. Contact: Special Research Symposium Issue, 40(2), 68-83. http:// www.teslontario.net/uploads/publications/researchsymposium/ResearchSymposium 2014. pdf

Fox, J. (2015). Trends and issues in language assessment in Canada: A consideration of context. Language Assessment Quarterly, 12(1), 1-9. https://doi.org/10.1080/15434303.2014.999921

Gardner, R. C., Masgoret, A.-M., Tennant, J., \& Mihic, L. (2004). Integrative motivation: Changes during a year-long intermediate-level language course. Language Learning, 54(1), 1-34. https://doi.org/10.1111/j.1467-9922.2004.00247.x

Hashemian, M., \& Fadaei, B. (2013). Fostering EFL learners' autonomy in light of portfolio assessment: Exploring the potential impact of gender. Iranian Journal of Language Teaching Research, 1(2), 135-151.

He, T. H. (2005). Effects of mastery and performance goals on the composition strategy use of adult EFL writers. The Modern Canadian Modern Language Review, 61(3), 407-431. https://doi. org $/ 10.3138 / \mathrm{cmlr} .61 .3 .407$

Hosseini, H., \& Ghabanchi, Z. (2014). The effect of portfolio assessment on EFL learners' reading comprehension and motivation. English Language Teaching, 7(5), 110-119.

Hsieh, H.-F., \& Shannon, S. E. (2005). Three approaches to qualitative content analysis. Qualitative Health Research, 15(9), 1277-1288. https://doi.org/10.1177/1049732305276687

Huang, H.-T. D., \& Hung, S.-T. A. (2010). Effects of electronic portfolios on EFL oral performance. Asian EFL Journal, 12(2), 192-212.

Hung, S.-T. A. (2009). Promoting self-assessment strategies: An electronic portfolio approach. Asian EFL Journal, 11(2), 129-146.

Hung, S.-T. A. (2012). A washback study on e-portfolio assessment in an English as a Foreign Language teacher preparation program. Computer Assisted Language Learning, 25(1), 21-36. https://doi.org/10.1080/09588221.2010.551756

Hung, S.-T. A., \& Huang, H.-T. D. (2016). Blogs as a learning and assessment instrument for English-speaking performance. Interactive Learning Environments, 24(8), 1881-1894. https:// doi.org/10.1080/10494820.2015.1057746

Jacobs, G. M., \& Farrell, T. S. C. (2001). Paradigm shift: Understanding and implementing change in second language education. TESL-EJ, $5,1$.

Johnson, K. E. (1996). The Role of Theory in L2 Teacher Education. TESOL Quarterly, 30(4), 765771. https://doi.org/10.2307/3587933

Kabilan, M. K., \& Khan, M. A. (2012). Assessing pre-service English language teachers' learning using e-portfolios: Benefits, challenges and competencies gained. Computers $\mathcal{E}$ Education, 58(4), 1007-1020. https://doi.org/10.1016/j.compedu.2011.11.011

Lai, E. R. (2011). Motivation: A literature review. Pearson. https://images.pearsonassessments.com/ images/tmrs/Motivation_Review_final.pdf

Lam, R. (2013). Two portfolio systems: EFL students' perceptions of writing ability, text 
improvement, and feedback. Assessing Writing, 18(2), 132-153. https://doi.org/10.1016/j. asw.2012.10.003

Linnenbrink, E. A., \& Pintrich, P. R. (2003). The role of self-efficacy beliefs in student engagement and learning. Reading \& Writing Quarterly, 19(2), 119-137. https://doi. org/10.1080/10573560308223

Lu, Y.-L., \& Wu, C.-W. (2018). An integrated evaluation model of teaching and learning. Journal of University Teaching and Learning Practice, 15(3), 1-17.

Ngoc Truong, T. N., \& Wang, C. (2019). Understanding Vietnamese college students' selfefficacy beliefs in learning English as a foreign language. System, 84, 123-132. https://doi. org/10.1016/j.system.2019.06.007

Nguyen, H. T. M., \& Bui, T. (2016). Teachers' agency and the enactment of educational reform in Vietnam. Current Issues in Language Planning, 17(1), 88-105. https://doi.org/10.1080/1466 4208.2016.1125664

Nicolaidou, I. (2013). E-portfolios supporting primary students' writing performance and peer feedback. Computers \& Education, 68, 404-415. https://doi.org/10.1016/j.compedu.2013.06.004

Nitta, R. (2013). Understanding motivational evolution in the EFL classroom. In M. T. Apple, D. Da Silva \& T. Fellner (Eds.), Understanding motivational evolution in the EFL classroom (pp. 268-290). Multilingual Matters. /https://doi.org/10.21832/9781783090518-017

Paulson, P. R., \& Paulson, F. L. (1991). Portfolios: Stories of knowing. [Paper presentation]. 54th annual meeting of the Claremont Reading Conference. https://files.eric.ed.gov/fulltext/ ED377209.pdf

Peacock, M. (1997). The effect of authentic materials on the motivation of EFL learners. ELT Journal, 51(2), 144-156. https://doi.org/10.1093/elt/51.2.144

Phan, N. L. H. (2018). Implications of the changing status of English for instructional models of English: A study of Vietnamese ELT teachers' reflections. TESOL Journal, 9(2), 368-387. https://doi.org/10.1002/tesj.331

Phung, T. L., \& Dang, T. T. (2016). The effect of speaking e-portfolios on learner autonomy for non-English major students at PetroVietnam University. Hirao School of Management Review, 6, 106-169.

Pintrich, P. R. (1989). The dynamic interplay of student motivation and cognition in the college classroom. Advances in Motivation and Achievement, 6, 117-160.

Pintrich, P. R., \& De Groot, E. V. (1990). Motivational and self-regulated learning components of classroom academic performance [Article]. Journal of Educational Psychology, 82(1), 33-40. https://doi.org/10.1037/0022-0663.82.1.33

Pintrich, P. R., Smith, D. A. F., Garcia, T., \& McKeachie, W. J. (1991). A manual for the use of the Motivated Strategies for Learning Questionnaire (MSLQ). The University of Michigan, National Center for Research to Improve Postsecondary Teaching and Learning.

Pintrich, P. R., Smith, D. A. F., Garcia, T., \& McKeachie, W. J. (1993). Reliability and predictive validity of the motivated strategies for learning questionnaire (MSLQ). Educational and Psychological Measurement, 53(3), 801-813. https://doi.org/10.1177/0013164493053003024

Ripley, D. (2012). Implementing portfolio-based language assessment in LINC programs: Benefits and challenges. TESL Canada Journal, 30(1), 69-86. https://doi.org/10.18806/tesl.v30i1.1126

Ryan, R. M., \& Deci, E. L. (2000a). Intrinsic and extrinsic motivations: Classic definitions and new directions. Contemporary Educational Psychology, 25(1), 54-67. https://doi.org/10.1006/ ceps.1999.1020

Ryan, R. M., \& Deci, E. L. (2000b). Self-determination theory and the facilitation of intrinsic motivation, social development, and well-being. American Psychologist, 55(1), 68-78. https:// doi.org/10.1037/0003-066x.55.1.68

Sharifi, M., Soleimani, H., \& Jafarigohar, M. (2017). E-portfolio evaluation and vocabulary learning: Moving from pedagogy to andragogy. British Journal of Educational Technology, 48(6), 1441-1450. https://doi.org/10.1111/bjet.12479

Thang, S. M., Lee, Y. S., \& Zulkifli, N. F. (2012). The role of the electronic portfolio in enhancing 
Information and Communication Technology and English language skills: The voices of six Malaysian undergraduates. Computer Assisted Language Learning, 25(3), 277-293. https://doi. org/10.1080/09588221.2012.655299

Tran T. Q. N., \& Le X. M. (2018). High school students' perceptions of the use of facebookbased e-portfolios in EFL writing: A case in the Mekong Delta, Vietnam. European Journal of Education Studies, 4(8).

Ushioda, E. (2012). Motivation: L2 Learning as a Special Case? In S. Mercer, S. Ryan, \& M. Williams (Eds.), Psychology for language learning: Insights from research, theory and practice (pp. 58-73). Palgrave Macmillan UK. /https://doi.org/10.1057/9781137032829_5

Vandergrift, L. (2007). Recent developments in second and foreign language listening comprehension research. Language Teaching, 40(3), 191-210. https://doi.org/10.1017/ S0261444807004338

Varasteh, H., Ghanizadeh, A., \& Akbari, O. (2016). The role of task value, effort-regulation, and ambiguity tolerance in predicting EFL learners' test anxiety, learning strategies, and language achievement. Psychological Studies, 61(1), 2-12. https://doi.org/10.1007/s12646-015-0351-5

Wigfield, A., \& Eccles, J. S. (2000). Expectancy-Value Theory of Achievement Motivation. Contemporary Educational Psychology, 25(1), 68-81. https://doi.org/10.1006/ceps.1999.1015 


\section{Appendix: L2 Listening Motivation Scale (L2LMS)}

\section{Intrinsic Motivation}

IM1. In a class like this, I prefer course material that really challenges me so I can learn new things.

IM2. In a class like this, I prefer course material that arouses my curiosity, even if it is difficult to learn.

IM3. The most satisfying thing for me in this course is trying to understand the content as thoroughly as possible.

IM4. When I have the opportunity in this class, I choose course assignments that I can learn from even if they don't guarantee a good grade.

\section{Extrinsic Motivation}

EM1. Getting a good grade in this class is the most satisfying thing for me right now.

EM2. The most important thing for me right now is improving my overall grade point average, so my main concern in this class is getting a good grade.

EM3. If I can, I want to get better grades in this class than most of the other students.

EM4. I want to do well in this class because it is important to show my ability to my family, friends, employer, or others.

\section{Task Value}

TV1. I think I will be able to use what I learn in this course in other courses.

TV2. It is important for me to learn the course material in this class.

TV3. I am very interested in the content area of this course.

TV4. I think the course material in this class is useful for me to learn.

TV5. I like the subject matter of this course.

TV6. Understanding the subject matter of this course is very important to me.

\section{Control of Learning Beliefs}

CLB1. If I study in appropriate ways, then I will be able to learn the material in this course.

CLB2. It is my own fault if I don't learn the material in this course.

CLB3. If I try hard enough, then I will understand the course material.

CLB4. If I don't understand the course material, it is because I didn't try hard enough.

\section{Self-Efficacy}

SE1. I believe I will receive an excellent grade in this class.

SE2. I'm certain I can understand the most difficult material presented in the readings for this course.

SE3. I'm confident I can learn the basic concepts taught in this course. 
SE4. I'm confident I can understand the most complex material presented by the instructor in this course.

SE5. I'm confident I can do an excellent job on the assignments and tests in this course.

SE6. I expect to do well in this class.

SE7. I'm certain I can master the skills being taught in this class.

SE8. Considering the difficulty of this course, the teacher, and my skills, I think I will do well in this class. 